\title{
Correction to: a hybrid technique combining intramedullary pinning with extramedullary plate fixation in unstable and comminuted radial head fractures following on-table reconstruction
}

\author{
Xu Gao ${ }^{1}$, Shi-you Dai ${ }^{2}$, Hai-lei Yin ${ }^{3 *}$, Fei Li ${ }^{3}$, Yong-qiang Sui ${ }^{4}$, Rui Huang ${ }^{3}$ and Hai-yu Fan ${ }^{5}$
}

Correction to: BMC Musculoskelet Disord 22, 613 (2021).

https://doi.org/10.1186/s12891-021-04498-w

Following the publication of the original article [1] the authors noticed that the correction in Table 1 "the number of males is supposed to be 8 and the number of females is supposed to be 5 " was not implemented. The original article [1] has been updated.

Below is the correct Table 1.

The original article can be found online at https://doi.org/10.1186/s12891 021-04498-w.

* Correspondence: stonethrough@yeah.net

${ }^{3}$ Department of Second Orthopaedic Surgery, No. 971 Hospital of the

People's Liberation Army (PLA), Qingdao City 266071, People's Republic of

China

Full list of author information is available at the end of the article

C The Author(s). 2021 Open Access This article is licensed under a Creative Commons Attribution 4.0 International License, which permits use, sharing, adaptation, distribution and reproduction in any medium or format, as long as you give appropriate credit to the original author(s) and the source, provide a link to the Creative Commons licence, and indicate if changes were made. The images or other third party material in this article are included in the article's Creative Commons licence, unless indicated otherwise in a credit line to the material. If material is not included in the article's Creative Commons licence and your intended use is not permitted by statutory regulation or exceeds the permitted use, you will need to obtain permission directly from the copyright holder. To view a copy of this licence, visit http://creativecommons.org/licenses/by/4.0/. The Creative Commons Public Domain Dedication waiver (http://creativecommons.org/publicdomain/zero/1.0/) applies to the data made available in this article, unless otherwise stated in a credit line to the data. 
Table 1 Details of patient demographics

\begin{tabular}{lll}
\hline & ORIF (experimental) & RHR (control) \\
\hline Patients [13] & 6 & 7 \\
Male [8] & 3 & 5 \\
Female [5] & 3 & 2 \\
Mean \pm SD age [years] & $37.1 \pm 9.0$ & $41.7 \pm 7.7$ \\
Side of the injury [13] & - & - \\
$\quad$ Right [9] & 4 & 5 \\
Left [4] & 2 & 2 \\
Mean \pm SD time of follow-up [months] & $38.6 \pm 4.5$ & $32.0 \pm 6.3$ \\
Mode of injury [13] & - & - \\
Falling injury [4] & 3 & 1 \\
Traffic accident [9] & 3 & 6 \\
\hline
\end{tabular}

\section{Author details}

'Department of Orthopaedic Surgery, Qingdao University, Qingdao City 266071, People's Republic of China. ${ }^{2}$ Department of Bone, Joint and Sports Medicine, East District, Qingdao Municipal Hospital, Qingdao City 266071, People's Republic of China. ${ }^{3}$ Department of Second Orthopaedic Surgery, No. 971 Hospital of the People's Liberation Army (PLA), Qingdao City 266071, People's Republic of China. ${ }^{4}$ Department of State Key Laboratory for Marine Corrosion and Protection, Luoyang Ship Material Research Institute, Qingdao City 266071, People's Republic of China. ${ }^{5}$ Department of Burn and Plastic Surgery, No. 971 Hospital of the People's Liberation Army (PLA), Qingdao City 266071, People's Republic of China.

Published online: 09 August 2021

\section{Reference}

1. Gao X, Dai SY, Yin HL, et al. A hybrid technique combining intramedullary pinning with extramedullary plate fixation in unstable and comminuted radial head fractures following on-table reconstruction. BMC Musculoskelet Disord. 2021;22:613 https://doi.org/10.1186/s12891-021-04498-w. 